\title{
Antioxidant, polyphenol and sensory analysis of cherry tomato varieties and landraces
}

\author{
Divéky-Ertsey, A. a, Csambalik, L. a, Kókai Z. b, Stefanovits-Bányai É.c, Pap Z. d, \\ Krisztiánné Kis, M. ${ }^{d} \&$ Sipos, L. ${ }^{\text {** }}$ \\ ${ }^{a}$ Corvinus University of Budapest, Faculty of Horticultural Science, Department of Ecological and Sustainable \\ Production Systems, H-1118 Budapest, Villányi út 29-43. Hungary \\ ${ }^{b}$ Corvinus University of Budapest, Faculty of Food Science, Sensory Laboratory, \\ H-1118 Budapest, Villányi út 29-43. Hungary*(laszlo.sipos@uni-corvinus.hu) \\ ${ }^{c}$ Corvinus University of Budapest, Faculty of Food Science, Department of Applied Chemistry, \\ H-1118 Budapest, Villányi út 29-43. Hungary \\ ${ }^{d}$ Corvinus University of Budapest, Faculty of Horticultural Science, Department of Vegetable and Mushroom \\ Growing, H-1118 Budapest, Villányi út 29-43. Hungary
}

\begin{abstract}
Summary: Among vegetables produced both for raw consumption and processing, tomato is one of the most important one in Europe, by production area and by yield as well. In the past years several study dealt with the investigation of the inner content of tomato, with special regards to antioxidant content. In this paper cherry tomato varieties and landraces from conventional and organic production were compared. Besides basic investigations sensory analysis were designed and Antioxidant Capacity (AOC) and Total Phenol Content (TPC) were measured. The aim of the research was to compare varieties and to study the effect of variety and production methods on antioxidant capacity and sensory profiles.
\end{abstract}

Key words: cherry tomato, variety trials, antioxidant capacity, sensory profiles

\section{Introduction}

Production of tomato (Lycopersicon lycopersicum (L.) Karsten) has long traditions in Hungary, both in open field and in forcing. In the past three years the average of harvested area was two thousand hectares with the yield of 180 thousand tons (KSH STADAT 2011). In 2010, Hungary was the tenth among tomato grower counties in the EU (EUSTAT). A key point of successful production is variety selection. Producers favour resistant varieties with sufficient yield, which is popular among consumers as well. However, today not only shape, size, surface, colour, flesh consistency, storage characteristics and taste are the only points for consumers and producers, but inner values, such as sugar/acid ratio and antioxidant capacity are considerable characteristics as well (Beecher, 1998). When comparing varieties, these parameters should also be taken into consideration.

Nowadays there is an increasing interest in the usage of landraces as a possible direction of market expansion and that of sustaining biodiversity in organic farming. However, until now commercial production of landraces was not permitted. In 2009 the directive of the EU has been published (Commission Directive 2009/145/EC (26 November 2009) providing for certain derogations, for acceptance of vegetable landraces and varieties which have been traditionally grown in particular localities and regions and are threatened by genetic erosion and of vegetable varieties with no intrinsic value for commercial crop production but developed for growing under particular conditions and for marketing of seed of those landraces and varieties).

In 2011 the Hungarian directive has been published according to the one above called 65/2011. (VII.11.) VM Regulation for the acceptance of landraces and home-garden races of vegetable varieties and for the conditions of seed production and commercialization of these varieties.

According to the regulations, following a simplified investigation landraces can be included into the National Variety Catalogue, which permits the commercial production and marketing of a given landrace.

The risk of chronic diseases may be reduced by the consumption of essential compounds from plant sources and special products, which, at the same time, helps to maintain good physical conditions (Block et al., 1992; Liu et al., 2000; Hung et al., 2004; Willis et al.; 2009).

Several investigations based on the hypothesis, that tomato consumption in different forms can have preventive effect on the development of certain diseases associated with tumors (Etminan et al., 2004). Based on epidemiological investigations this favorable effect can be justified by the antioxidants present in tomato fruit (Binoy et al., 2004). 
Antioxidant capacity is the capability of a compound to inhibit oxidative degradation (Roginsky \& Lissi, 2005). There are over 20 methods developed for the assessment of antioxidant capacity (Frankel\&Meyer, 2000). Antioxidant capacity of certain varieties can be an important information for the industry which variety to be used and for consumers which one to prefer (Balogh, 2010).

\section{Materials and method}

\subsection{Tomato varieties}

Panarea: Cherry type tomato, with continuous, strong growing cast, recommended for long term forcing and for field as well. It has LSL attribution also. Weights of fruit: 1825g. Owner of variety: Monsanto (USA).

CLX37379: Cherry type tomato, with continuous growing cast, recommended for long term forcing. It has LSL attribution also. Weights of fruit: 20-25 g. Owner of variety: Clause (France).

Zuccherino: The variety has extra strong and fast growing attribute with continuous growing type. It is recommended mainly for forcing and also for field growing. Tomato is typified with early maturity. Shape of fruit is mildly pear (mini san marzano). Taste of fruit is delicious because of higher sugar content. Fruits are susceptible for early trill. Weight of fruit: 17-25 g, average of Brix ${ }^{\mathrm{o}}$ : 11. Owner of variety: Cora seed (Italy).

Cello: The variety has strong and fast growing type, with middle-early maturity. The shape of fruit is plum form. Fruits have definitely delicious taste and LSL attribution. Weights of fruit: 14-16 g Owner of variety: Monsanto (USA).

Landrace of Bugac: Main-season, indeterminate landrace collected from Bugac town, Hungary. Light red, slightly flattened, globe-shaped fruits of a 20-25 g average weight, $8 \mathrm{~kg} / \mathrm{m}^{2}$ total yield (2011).

Landrace of Máriapócs: Main-season, indeterminate landrace collected from Máripócs, Hungary. Bright red, sphere shaped small, sweet fruits of 10-16 g average weight, $10 \mathrm{~kg} / \mathrm{m}^{2}$ total yield (2011).

\subsection{Instrumental measurements of weights and inner contents}

In instrumental measurement the laboratory of Department of Vegetable and Mushroom Growing examined average weight of one tomato fruit, sugar-acid ratio, and Brix $^{\circ}$. Weight parameters of average sample were measured at arrival to the laboratory, while refraction- and titratable acid content were defined later on after washing and freezing. Varieties were measured in three repetitions after dissolvation.

Weight of investigated varieties was measured by KPZ-205-4/6000 type digital scale. Water soluble dry matter content was measured according to the rules of CODEX
ALIMENTARIUS 3-1-558/93 with ATAGO PR-101 type digital refractometer. Titratable total acid content was measured with $0,1 \mathrm{n} \mathrm{NaOH}$ solution, with the attendance of phenolphthalein indicator, according to MSZ EN No. 12147:1998 Hungarian Pattern.

Tomato varieties were harvested in ,economical stage”, in four fractions. Tomato varieties were washed before measuring. Both repetitions were homogenized separately by hand blender and filled into test tubes. Mixtures were freezed in $-32{ }^{\circ} \mathrm{C}$ until measurement. The supernatant was centrifuged at $12500 \mathrm{rpm}$ and used for analysis (Benzie \& Strain, 1996). Antioxidant capacity was determined using FRAP assay (Benzie \& Strain, 1996) spectrophotometrically at $593 \mathrm{~nm}$. Ascorbic acid was used as control to obtain the standard curve. FRAP value was calculated relevant to the activity of ascorbic acid (AA) and expressed as ascorbic acid equivalents. Results were provided in mg AA/1 dimension.

Total Phenol Content was measured using FolinCiocalteu's reagent according to the method of Singleton and Rossi (1965). Absorbance was monitored spectrophotometrically at $760 \mathrm{~nm}$ and the content of soluble phenols was calculated from a standard curve based on gallic acid (GA) concentrations. Results were provided in mg GA/l dimension. Every measurement was repeated 3 times and data are presented as mean.

Relationships between products, sensory attributes and instrumental measurements were determined by the PCA method after standardization. We used standardized PCA biplot (Naes et al., 2010).

\subsection{Sensory analysis}

Sensory profile analysis method was chosen from many reliable, descriptive methods that are designed to take all of the relevant human senses into account. The chosen method can be used to define a product standard and to compare a product with those of similar type already on the market. The sensory profile analysis is one of the most complex food tests with the main advantage: being able to give a full description of a food product by rating its characteristics and their relative intensities on a numerical scale (Meilgaard et al., 1999).

International standard requires 8-16 people for product assessment (ISO, 1994), using this standard as a guide 16 people were selected for the trained sensory panel. The experiment was held in the sensory laboratory facilities at CUB, which fully meet all required ISO (1994) standards. In the first round, the product attributes were evaluated and noted by tasters. The sensory test was implemented by computers organized in a LAN structure. The data were collected and evaluated with the ProfiSens software developed by Technical University of Budapest and the Sensory Laboratory of CUB (Kókai et al., 2004). Every tasting was repeated two times. Statistical significance was determined by t-test depending on the equality of variances (F-Test) (Steel et al., 1996). 
Table 1. Antioxidant capacity of tomato extracts

\begin{tabular}{|c|l|c|c|c|c|c|}
\hline $\begin{array}{c}\text { Variety } \\
\text { No. }\end{array}$ & \multicolumn{1}{|c|}{ Variety } & Replicate & Mean & $\begin{array}{c}\text { St. } \\
\text { deviation }\end{array}$ & $\begin{array}{c}\text { Mini- } \\
\text { mum }\end{array}$ & $\begin{array}{c}\text { Maxi- } \\
\text { mum }\end{array}$ \\
\hline 1 & Panarea & 12 & 543,8 & 67,61 & 421,76 & 679,41 \\
\hline 2 & CLX37379 & 12 & 461,76 & 129,7 & 329,41 & 711,76 \\
\hline 3 & Zuccherino & 12 & 554,17 & 87,4 & 450 & 676,47 \\
\hline 4 & Cello & 12 & 390,44 & 165,62 & 132,35 & 626,47 \\
\hline 5 & Bugaci & 12 & 507,85 & 87,13 & 376,45 & 665,61 \\
\hline 6 & Máriapócsi & 12 & 525,35 & 64,16 & 431,01 & 616,51 \\
\hline
\end{tabular}

\section{Results and discussion}

\subsection{Antioxidant Capacity and Total Phenol Content of tomato extracts}

Our data demonstrate that differences can be found between varieties with regards to antioxidant capacity and polyphenol content as well. Zuccherino variety has the highest average antioxidant capacity with the value of 554,17 $\pm 87,4 \mathrm{mg}$ AA/l, followed close by Panarea, Máripócsi landrace, Bugaci landrace and CLX37379. The variety Cello has the lowest average antioxidant capacity with $390,44 \pm 165,62 \mathrm{mg} \mathrm{AA} / \mathrm{l}$ as it provided the lowest values in the examination.

Higher differences were experienced in Total Polyphenol Content (TPC) of tomato varieties. Both landraces provided far higher values than other ones. Average Total Polyphenol Content was the highest in case of Máriapócsi landrace with the value of $793,94 \pm 46,98 \mathrm{mg} \mathrm{GA} / 1$ followed by Bugaci landrace, which reached the highest maximum of 1030,4 mg GA/l. The four other varieties resulted a value around $500 \mathrm{mg}$ GA/l. The lowest average TPC were provided by Panarea variety.

\subsection{Sensory analysis}

Among examined fourteen sensory attributes, the following ones provided significant difference (LSD99\%): separation from stem, shape, size, colour intensity, ratio of cover colour, juicyness. Significant differences between varieties are shown in Table 3. Examined varieties can be accepted as similar in the following points: skin thickness, skin toughness, symmetry, global odour intensity, flesh sweetness, flesh acidity, after-taste, offflavour. Summarized sensory profile of examined varieties is shown in Figure 1.
Table 2. Total Phenol Content of tomato extracts

\begin{tabular}{|c|l|c|c|c|c|c|}
\hline $\begin{array}{c}\text { Variety } \\
\text { No. }\end{array}$ & \multicolumn{1}{|c|}{ Variety } & Replicate & Mean & $\begin{array}{c}\text { St. } \\
\text { deviation }\end{array}$ & $\begin{array}{c}\text { Mini- } \\
\text { mum }\end{array}$ & $\begin{array}{c}\text { Maxi- } \\
\text { mum }\end{array}$ \\
\hline 1 & Panarea & 12 & 488,08 & 67,71 & 382,7 & 603,16 \\
\hline 2 & CLX37379 & 12 & 519,53 & 87,52 & 415,97 & 669,72 \\
\hline 3 & Zuccherino & 12 & 527,42 & 80,69 & 391,01 & 654,12 \\
\hline 4 & Cello & 12 & 502,55 & 83,38 & 425,33 & 695,72 \\
\hline 5 & Bugaci & 12 & 783,81 & 145,84 & 611,83 & 1030,4 \\
\hline 6 & Máriapócsi & 12 & 793,94 & 46,98 & 714,29 & 843,09 \\
\hline
\end{tabular}

The first and second Profile Component accounts for $89,3 \%$ of the explained variance, which is a very good result. The relationship between varieties, instrumental measurements and sensory results is demonstrated in PCA Bi-plot figure. The sensory attributes positioned close to the variety are characteristic to it. This is true for the distance of sensory-sensory and instrumental-instrumental correlation as well. As an example, high BRIX, high dry matter content and high refraction is characteristic to Zuccherino variety, which is justified by the parameter of flesh sweetness as well. According to measured values, high weight is characteristic to the landrace of Máriapócs, which obviously shows good correlation with the sensory parameter of size. Panarea and CLX37379 are positioned close to each other on the PCA Biplot, both sensory and instrumental characteristics are similar. Landrace of Bugac can be characterized by high

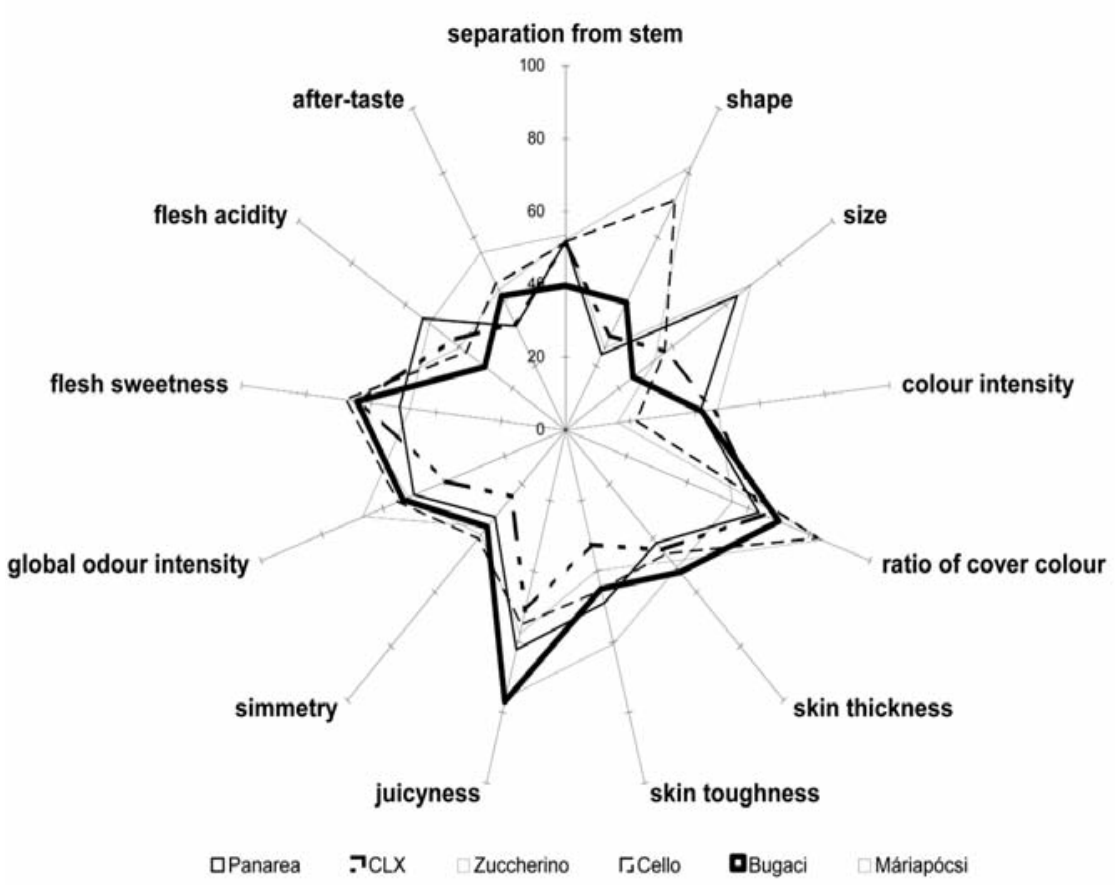

Fig. 1. Sensory profiles of examined tomato varieties 
titratable acid and flesh sweetness sensory parameter, shifting to the direction of sweetness. (Figure 2.)

\subsection{Instrumental measurement of weight and inner content}

The ideal sugar-acid ratio of tomato is $8-12 \%$. Under $8 \%$ tomato is tasteless, while above $12 \%$ it is sour. According to literature refraction of tomato is between 3,9 and 4,5 (YAMAGUCHI, 1983), while some of the investigated varieties showed higher values. Therefore the two sweet varieties (Zuccherino, Cello) and one of landraces exceeds literature data concerning refraction. Early literature shows, that reducing sugar content of some varieties reached, or even exceeded $6,5 \%$. The acid ration defined in citric acid is about $0,4-0,6 \%$ in literature, from which no deviation were examined in the present study (BENTON, 2008).

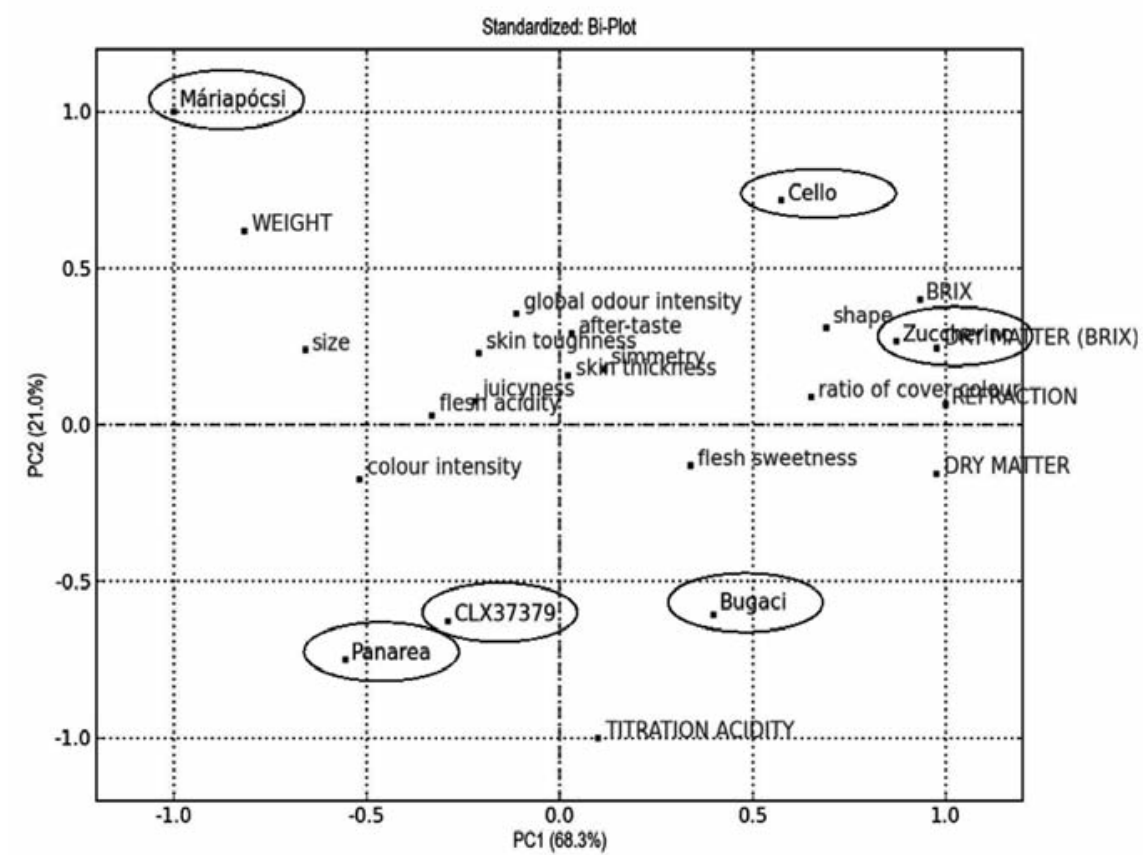

Fig. 2. Correlations between tomato varieties, sensory attributes and instrumental parameters by standardized PCA bi-plot

Table 3. Significant differences of significance attributes of tomato varieties

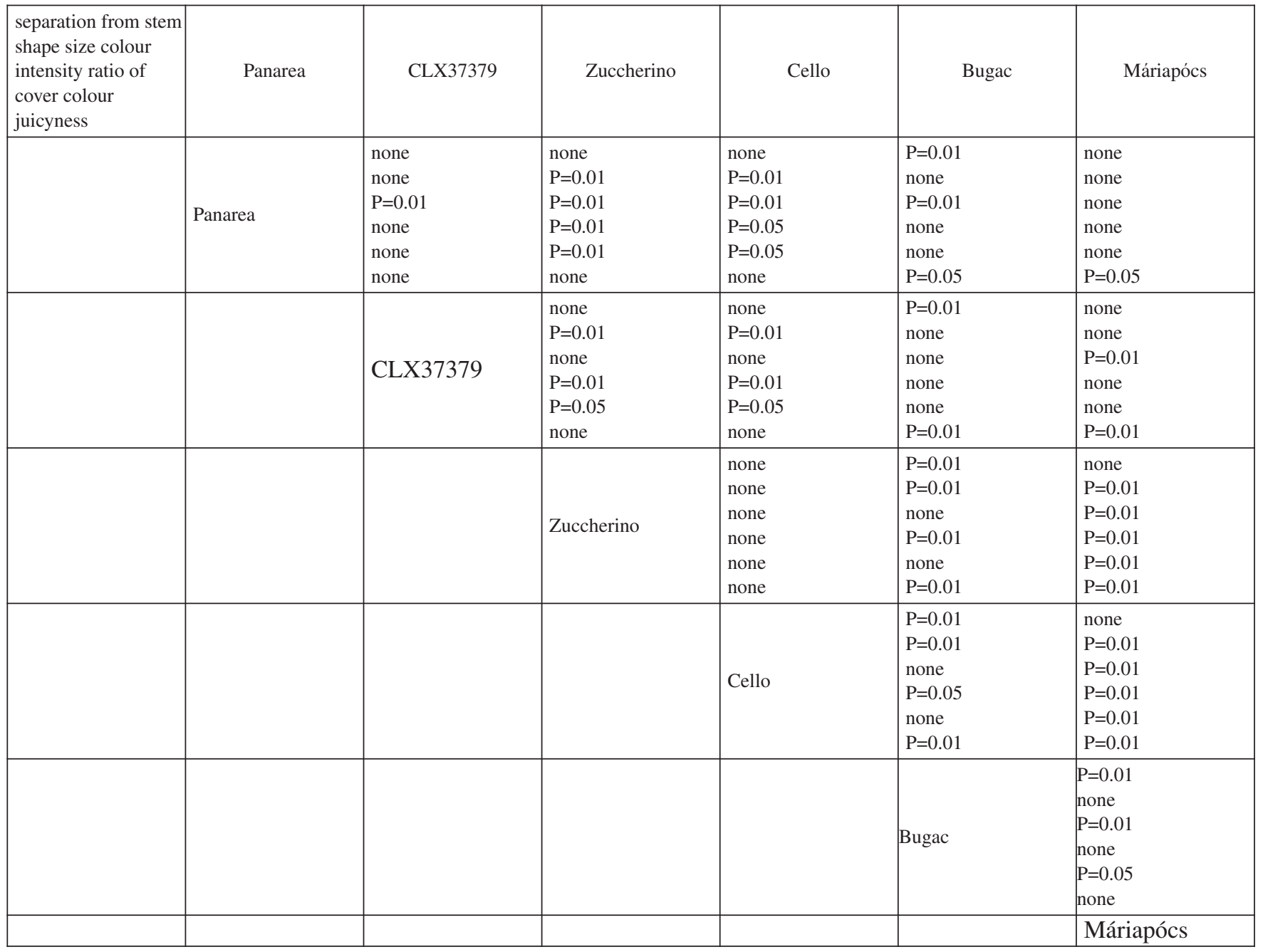


In case of Zuccherino variety we did not manage to justify BRIX $^{\circ}$ value 11 as it is stated in variety characterization, though the variety might reach even this high value as it is visible according to deviation. With regards to sugar-acid ratio all varieties performed according to literature, except Cello variety (Table 4.).

Table 4. Refraction and weight results of varieties

\begin{tabular}{|l|c|c|c|c|c|c|}
\hline \multicolumn{1}{|c|}{ Variety } & $\begin{array}{c}\text { Dry } \\
\text { matter } \\
\%\end{array}$ & $\begin{array}{c}\text { Re- } \\
\text { fraction } \\
\%\end{array}$ & $\begin{array}{c}\text { Titration } \\
\text { acidity\% }\end{array}$ & $\begin{array}{c}\text { Brix } \\
\text { mean }\end{array}$ & $\begin{array}{c}\text { Dry } \\
\text { matter } \\
(\text { Brix })\end{array}$ & $\begin{array}{c}\text { Weight } \\
(\mathrm{g})\end{array}$ \\
\hline Panarea & 8,79 & 4,51 & 0,57 & $\begin{array}{c}6,61 \\
\pm 0,10\end{array}$ & 8,67 & $\begin{array}{c}19,9 \\
\pm 2,6\end{array}$ \\
\hline CLX37379 & 8,72 & 4,51 & 0,52 & $\begin{array}{c}6,78 \\
\pm 0,06\end{array}$ & 8,89 & $\begin{array}{c}17,8 \\
\pm 2,2\end{array}$ \\
\hline Zuccherino & 10,25 & 6,13 & 0,51 & $\begin{array}{c}8,34 \\
\pm 0,15\end{array}$ & 9,97 & $\begin{array}{c}15,7 \\
\pm 1,5\end{array}$ \\
\hline Cello & 9,76 & 5,98 & 0,45 & $\begin{array}{c}8,11 \\
\pm 0,10\end{array}$ & 9,69 & $\begin{array}{c}18,2 \\
\pm 2,7\end{array}$ \\
\hline Bugaci & 10,16 & 5,48 & 0,56 & $\begin{array}{c}7,43 \\
\pm 0,06\end{array}$ & 9,52 & $\begin{array}{c}14,3 \\
\pm 2,6\end{array}$ \\
\hline Máriapócsi & 7,98 & 3,83 & 0,44 & $\begin{array}{c}6,75 \\
\pm 0,07\end{array}$ & 8,73 & $\begin{array}{c}29,7 \\
\pm 8,2\end{array}$ \\
\hline
\end{tabular}

\section{Conclusions}

In our investigation six varieties were measured according to sensory, instrumental and inner content characteristics. Four of them are marketable varieties, while two are Hungarian landraces from the Middle-Hungarian region.

According to sensory analysis, it was shown that varieties differ in the following attributes: separation from stem, shape, size, colour intensity, ratio of cover colour, juicyness. No significant difference was given in characteristics with regards to inner content. However, instrumental investigations showed that Zuccherino, Cello and Bugaci landrace, respectively, exceeded the values defined in literature as average refraction value. This was clearly justified by PCA Bi-plot as well, as both three varieties are situated close to sweet attributes, like refraction and flesh sweetness.

Bi-plot analysis further showed, that, besides few obvious interactions (Zuccherino - dry matter, BRIX, Máriapócsi landrace - size, CLX37379 and Panarea - colour intensity and flesh sweetness), most attributes are in equal distance to all varieties, therefore not especially characteristic to them.

Instrumental measurements confirmed the results of sensory investigations, like in case of flesh sweetness of Zuccherino variety and Bugaci landrace and of big size of Máriapócsi landrace.

There were only small differences in AOC of varieties, only Cello variety showed lower values. This attribute of varieties might have genetic background.

With regards to TPC it was clearly shown, that methods of production basically influence this attribute. Landraces showed higher values than marketable ones. This is due to the fact, that the latter varieties were grown in glass house, while landraces were grown in open field. As it is known, in case of high temperature and intensive sunlight polyphenol content is increasing, especially in case of extreme UV-B radiance (BRANDT, 2007). This justifies the fact, that open field landraces reached higher values in TPC in contrast with other four varieties.

This study was supported by TÁMOP-4.2.1./B-09/1/KMR 2010-0005 „Improvement of quality of higher education through research-development, innovation and education development" project.

\section{References}

Balogh, E., Hegedús, A. \& Stefanovits-Bányai, É. (2010): Application of and correlation among antioxidant and antiradical assays for characterizing antioxidant capacity of berries. Scientia Horticulturae, 125: 332-336.

Beecher, G.R. (1998): Nutrient content of tomatoes and tomato products. Proc Soc Exp Biol Med., 218. (2): 98-100.

Benton, J.J. (2008): Fruit characteristics in Tomato Plant Culture. CRC Press Taylor \& Francis Group, LLC, USA, 101-129.

Benzie, I.I.F. \& Strain J.J. (1996): The ferric reducing ability of plasma (FRAP) as a measure of ,,antioxidant power": The FRAP assay. Anal. Biochem., 239: 70-76.

Binoy, G., Charanjit, K., Khurdiya, D.S. \& Kapoor, H.C. (2004): Antioxidants in tomato (Lycopersium esculentum) as a function of genotype. Food Chemistry, 84. (1): 45-51.

Block, G., Patterson, B. \& Subar, A. (1992): Fruit, vegetables and cancer prevention - a review of the epidemiologic evidence. Nutr. Cancer, 18: 1-29.

Brandt, S. (2007): A termesztési körülmények és a fajta hatása a paradicsom beltartalmi értékeire. $\mathrm{PhD}$ dissertation. Szent István Egyetem, Gödöllö, 91-96.

Codex Alimentarius Hungaricus 3-1-558/93 Feldolgozott zöldség- és gyümölcstermékek vízben oldható szárazanyagtartalmának meghatározása

Etminan, M., Takkouche, B. \& Caamaño-Isorna, F. (2004): The Role of Tomato Products and Lycopene in the Prevention of Prostate Cancer: A Meta-Analysis of Observational Studies. Cancer Epidemiol Biomarkers Prev., 13: 340-345.

Frankel, E.N. \& Meyer, A.S. (2000): The problems using onedimensional methods to evaluate multifunctional food and biological antioxidants. J. Sci. Food Agric., 80: 1925-1941.

Hung, H.C., Joshipura, K.J., Jiang, R., Hu, F.B., Hunter, D., Smith-Warner, S.A., Colditz, G.A., Rosner, B., Spiegelman, D. \& Willett, W.C. (2004): Fruit and vegetable intake and risk of major chronic disease. J. Natl. Cancer, 196: 1577-1584.

ISO (1994): Sensory analysis - Identification and selection of descriptors for establishing a sensory profile by a multidimensional approach. No: 11035

Kókai, Z., Heszberger, J., Kollár-Hunek, K. \& Papp, E. (2004): ProfiSens - A profile analysis supporting software in food industry, related research and education. Per. Polytechn. Chem. Eng., (1): $31-40$. 
Liu, S., Manson, J.E., Lee, I.M., Cole, S.R., Hennekens, C.H., Willet, W.C. \& Buring, J.E. (2000): Fruit and vegetable intake and risk of cardiovascular disease: the Women's Health Study. Am. J. Clin. Nutr., 72: 922-928.

Lugasi A., Hóvári J., Bíró L., Brandt S. \& Helyes L. (2004): Élelmiszereink likopin-tartalmát befolyásoló tényezők és a hazai lakosság likopinbevitele. Magyar onkológia, 48. (2): 131-136.

Meilgaard, M., Civille, G. V., Carr, B. T. (1999): Sensory Evaluation Techniques, New York: CRC Press., 5-387.

MSZ EN No. 12147:1998 Gyümölcs- és zöldséglevek. A titrálható savasság meghatározása.

Naes, T., Brockhoff, P. B. \& Tomic, O. (2010): Statistics for sensory and consumer science. Wiley, Chicester., 209-226.

Roginsky, V. \& Lissi, E. A. (2005): Review of methods to determine chain-breaking antioxidant activity in food. Food Chem., 92: 235-254.
Singleton, V.L. \& Rossi, J.A. (1965): Colorimetry of total phenolics with phosphomolibdic-phosphotungstic acid reagents. Am. J. Enol. Viticult., 161: 144-158.

Steel, R.G.D., Torrie, J.H. \& Dickey, D. (1996): Principles and procedures of statistics. McGraw-Hill, New York, USA, General Papers

Weisburger, J.H. (1999): Mechanisms of action of antioxidants as exemplified in vegetables, tomatoes, and tea. Food Chem. Toxicol., 37: 943-948.

Willis, L.M., Shukitt-Hale, B. \& Joseph, J.A. (2009): Modulation of cognition and behaviour in aged animals: role for antioxidantand essential fatty acid-rich plant foods. Am. J. Clin. Nutr., 89.

Yamaguchi, M. (1983): Solanaceous Fruits: Tomato, Eggplant, Peppers and Others in World vegetables. The AVI Publishing Company, Connecticut, USA, 291-298. 